\title{
Menakar Partisipasi Pemilih Pemula dalam Pemilihan Kepala Daerah di Masa Pandemi Covid-19
}

\section{Measuring Beginner Voter Participation in Regional Head Elections in The Covid-19 Pandemic}

\author{
Khairunnisa Maulida*, Hertanto, Robi Cahyadi Kurniawan \& Arizka \\ Warganegara \\ Magister Ilmu Pemerintahan, Fakultas Ilmu Sosial dan Ilmu Politik, \\ Universitas Lampung, Indonesia
}

Diterima: 17 Juli 2021; Disetujui: 15 Desember 2021; Dipublish: 01 Januari 2022

\begin{abstract}
Abstrak
Artikel ini bertujuan untuk menakar partisipasi pemilih pemula dalam pemilihan kepala daerah di masa pandemic Covid-19 dalam pemilihan wali kota dan wakil wali kota di Bandar Lampung tahun 2020. Masalah difokuskan pada pemilih pemula mempunyai posisi strategis dalam Pilwakot Bandar Lampung tahun 2020. Persentase partisipasi pemilih pemula pada pemilu 2019 adalah $20 \%$ dari total partisipasi pemilih secara keseluruhan. Guna mendekati masalah ini dipergunakan acuan teori dari Gabriel Almond tentang bentuk-bentuk partisipasi politik. Data-data dikumpulkan melalui survey online menggunakan google form dan dianalisis secara kualitatif. Kajian ini menyimpulkan yakni, Pertama 92\% responden mengetahui pada Bulan Desember tahun 2020 di Bandar Lampung akan diselenggarakan Pilwakot dan 79,5 \% pemilih pemula menggunakan hak pilih nya secara sukarela. Kedua, $47,3 \%$ pemilih pemula pernah melakukan protes terhadap kebijakan yang dibuat oleh Pemerintah dan 70,5\% responden tidak mengikuti acara debat publik calon wali kota dan wakil wali Kota Bandar Lampung tahun 2020. Ketiga, pemilih pemula dalam memilih pasangan calon wali kota dan wakil wali kota tidak dipengaruhi oleh money politik dengan persentase $96,4 \%$. Keempat, $81,3 \%$ pemilih pemula menjawab mereka tidak dipengaruhi oleh orangtua dalam menggunakan hak pilih dan Kesadaran pemilih pemula menggunakan hak pilih sebagai warga negara sebanyak 97, 3\%.
\end{abstract}

Kata Kunci: Pemilih Pemula; Partisipasi; Pandemi

\section{Abstract}

This article aims to measure the participation of novice voters in the regional head election during the Covid-19 pandemic in the election of mayor and deputy mayor in Bandar Lampung in 2020. The problem is focused on beginner voters who have a strategic position in the 2020 Bandar Lampung Election. beginners in the 2019 election is $20 \%$ of the total voter turnout as a whole. In order to approach this problem, Gabriel Almond's theoretical reference on forms of political participation is used. The data was collected through an online survey using google form and analyzed qualitatively. This study concludes that, first, 92\% of respondents know that in December 2020 in Bandar Lampung there will be an election for Wakot and $79.5 \%$ of novice voters exercise their right to vote voluntarily. Second, $47.3 \%$ of novice voters have protested against policies made by the government and $70.5 \%$ of respondents did not participate in the public debate of the mayor and deputy mayor of Bandar Lampung in 2020. Third, novice voters in choosing a candidate for mayor and the deputy mayor is not influenced by money politics with a percentage of $96.4 \%$. Fourth, 81.3\% of novice voters answered that they were not influenced by their parents in using their right to vote and Awareness of novice voters using their right to vote as citizens was $97.3 \%$.

Keyword: Beginner Voters; Participation; Pandemic

How to Cite: Maulida, K., Hertanto,Kurniawan, R.C., \& Warganegara, A. (2022). Menakar Partisipasi Pemilih Pemula dalam Pemilihan Kepala Daerah di Masa Pandemi Covid-19, PERSPEKTIF, 11 (1) :286298

*Corresponding author:

E-mail: Khairunnisamaulida123@gmail.com

ISSN 2085-0328 (Print)

ISSN 2541-5913 (online) 


\section{PENDAHULUAN}

Pilkada serentak tahun 2020 di Provinsi Lampung diselenggarakan di delapan Kabupaten/Kota termasuk Kota Bandar Lampung. Pilkada serentak tahun 2020 merupakan pilkada yang berbeda dengan pilkada sebelumnya.

Pilkada tahun 2020 dalam persiapan pelaksanaanya terganggu karena Pandemi Covid-19. Berdasarkan keputusan Komisi II Dewan Perwakilan Rakyat Republik Indonesia (DPR-RI), Pemerintah, dan jajaran pihak penyelenggara pemilu memutuskan kesiapan
Indonesia dalam menyelenggarakan pilkada serentak pada 9 Desember 2020 dengan berpedoman pada protokol kesehatan.

Corona Virus Disease 2019 (Covid-19) adalah penyakit jenis baru yang belum pernah di identifikasi sebelumnya pada manusia. Virus penyebab Covid-19 ini dinamakan Sars-CoV-2 (Kemenkes RI ,2020). Covid-19 telah menyebar hingga ke penjuru dunia, tidak terkecuali Provinsi Lampung. Berikut data Penyebaran Covid-19 di Provinsi Lampung :

Tabel 1. Penyebaran Covid-19 di Provinsi Lampung 3 November 2020

\begin{tabular}{cccccc}
\hline No & Kabupaten/Kota & $\begin{array}{c}\text { Kasus } \\
\text { Terkonfirmasi }\end{array}$ & $\begin{array}{c}\text { Selesai } \\
\text { Isolasi }\end{array}$ & $\begin{array}{c}\text { Jumlah } \\
\text { Kematian }\end{array}$ & $\begin{array}{c}\text { Resiko Kenaikan } \\
\text { Kasus }\end{array}$ \\
\hline 1 & Tulang Bawang Barat & 31 & 26 & 1 & Sedang \\
2 & Way Kanan & 26 & 20 & 2 & Sedang \\
3 & Lampung Utara & 177 & 158 & 4 & Sedang \\
4 & Lampung Barat & 41 & 37 & 1 & Sedang \\
5 & Pesisir Barat & 60 & 58 & 0 & Rendah \\
6 & Tanggamus & 63 & 39 & 2 & Sedang \\
7 & Pringsewu & 29 & 20 & 0 & Rendah \\
8 & Pesawaran & 64 & 42 & 4 & Sedang \\
9 & Bandar Lampung & 882 & 501 & 47 & Tinggi \\
10 & Lampung Selatan & 131 & 97 & 6 & Rendah \\
11 & Metro & 56 & 29 & 3 & Sedang \\
12 & Lampung Timur & 65 & 29 & 1 & Rendah \\
13 & Lampung Tengah & 215 & 190 & 7 & Sedang \\
14 & Tulang Bawang & 24 & 23 & 0 & Sedang \\
15 & Mesuji & 10 & 10 & 0 & Tidak \\
& & & & & Terdampak \\
\hline
\end{tabular}

Sumber : Dinas Kesehatan Provinsi Lampung, 2020.

Diketahui data dari tabel 1, bahwa Kota Bandar Lampung masuk dalam kategori tinggi resiko kenaikan kasus Covid-19. Pilkada serentak tahun 2020 di Kota Bandar Lampung akan diikuti oleh tiga pasangan calon dengan diusul oleh partai politik. Berikut data pasangan calon wali kota dan wakil wali kota di Bandar Lampung :

Tabel 2. Daftar Pasangan Calon Wali Kota dan Wakil Wali Kota Bandar Lampung tahun 2020

\begin{tabular}{rlr}
\hline No Urut & \multicolumn{1}{c}{ Nama Pasangan Calon } & Partai Pendukung \\
\hline 1. & H. Rycko Menoza S.E., S.H.MBA dan & Golkar dan PKS \\
& Ir. H. Johan Sulaiman,MM & \\
& M. Yusuf Kohar, S.E., MM & Demokrat, PAN, PKB, \\
& Drs. H. Tulus Purnomo W & Perindo, PPP \\
& Hj. Eva Dwiana, S.E & Drs. Deddy Amarullah
\end{tabular}

Sumber : kpukota_bandarlampung, 2020

Negara-negara yang memilih untuk tetap menggelar pemilu dimasa pandemic Covid-19 akan menghadapi tantangan. Salah satu yang terberat adalah "respon warga negara" yang berstatus pemilih dalam pemilu tersebut. (Hamzah, 2020). Republik Korea merupakan negara yang pertama menyelenggarakan pemilu di tengah ancaman pandemic Covid-19. 
(Spinelli, 2020). Penyelenggaraan Pemilu ditengah masa pandemic dengan ancaman penyebaran virus Covid-19 yang akan meningkat dan menyebabkan partisipasi pemilih menurun namun tidak untuk Korea Selatan. Kim (2020) menyebutkan bahwa :

"Despite concerns of a potential low turnout due to COVID-19 fears, 61.2 per cent of South Koreans voted this month - the highest voter turnout for the legislative election since 1996 - handing a landslide victory to the ruling party, which now has 180 out of 300 seats in parliament. The turnout underscores the South Korean government's effectiveness in providing a safe environment for voting amid a pandemic, as well as the public trust in the government"

Hasil penelitian Nurgiansah (2021) menyimpulkan bahwa partisipasi politik masyarakat Kabupaten Sleman di tengah pandemi sangat baik dengan angka pemilih 549.044 pemilih dan berbanding suara golput
126 suara. Dalam Pilkada di masa pandemic Covid-19 terhadap beberapa hal baru ditempat pemungutan suara yaitu dengan jumlah pemilih yang dikurangi, totalnya menjadi 500 pemilih satu TPS. Kemudian pengaturan kedatangan pemilih. Serta berbagai tahapan protokol kesehatan (Mashabi, 2020).

Beberapa hal baru tersebut merupakan upaya pemerintah dalam melindungi pemilih dari penyebaran virus Covid-19. Partisipasi politik masyarakat merupakan salah satu aspek penting di dalam sebuah negara demokrasi (Saputra, 2017). Pendapat tersebut selaras dengan yang diungkapkan oleh Arifin (2011) bahwa partisipasi merupakan "keterlibatan individu-individu dalam bermacam-macam tindakan dalam kehidupan politik". Berikutdata partisipasi pemilih di Provinsi Lampung dalam pemilihan umum terakhir yaitu pada tahun 2019 .

Tabel 3. Partisipasi Pemilih Di Provinsi Lampung Dalam Pemilihan Umum Tahun 2019

\begin{tabular}{rcrrc}
\hline \multirow{2}{*}{ No } & Kabupaten/ & \multicolumn{3}{c}{ Partisipasi Masyarakat dalam Pemilu } \\
& Kota & Pilpres & DPR RI & DPD RI \\
\hline 1 & Pringsewu & $83,27 \%$ & $83,23 \%$ & $83,23 \%$ \\
2 & Mesuji & $79,00 \%$ & $78,95 \%$ & $78,97 \%$ \\
3 & Tulang Bawang Barat & $85,88 \%$ & $85,85 \%$ & $85,86 \%$ \\
4 & Lampung Selatan & $77,70 \%$ & $77,62 \%$ & $77,63 \%$ \\
5 & Lampung Tengah & $78,27 \%$ & $78,25 \%$ & $78,21 \%$ \\
6 & Lampung Utara & $82,33 \%$ & $82,30 \%$ & $82,31 \%$ \\
7 & Lampung Barat & $85,25 \%$ & $85,13 \%$ & $85,14 \%$ \\
8 & Tulang Bawang & $78,87 \%$ & $78,77 \%$ & $78,78 \%$ \\
9 & Tanggamus & $76,35 \%$ & $76,31 \%$ & $76,29 \%$ \\
10 & Lampung Timur & $76,66 \%$ & $76,64 \%$ & $80,12 \%$ \\
11 & Way Kanan & $80,15 \%$ & $80,12 \%$ & $88,18 \%$ \\
12 & Bandar Lampung & $88,61 \%$ & $88,15 \%$ & $88,29 \%$ \\
13 & Metro & $88,51 \%$ & $87,97 \%$ & $82,64 \%$ \\
14 & Pesawaran & $82,67 \%$ & $82,67 \%$ & $81,09 \%$ \\
15 & Pesisir Barat & $81,16 \%$ & $81,07 \%$ & \\
\hline
\end{tabular}

Sumber:KPU Kota Bandar Lampung, 2019.

Berdasarkan tabel 3, diketahui bahwa persentase rata-rata tertinggi yaitu di Kota Bandar Lampung. Dalam sebuah pemilu kelompok pemilih pemula selalu menjadi sorotan karena mereka merupakan pemilih potensial yang perlu mendapatkan sosialisasi dari pelaksanaan pemilu (Widodo, Yoto. Gama, Betty. Kusumastuti, 2018). Selaras dengan pendapat sebelumnya, Mursyid \& Larissa (2021) dalam hasil penelitiannya menyebutkan bahwa KPU dalam meningkatkan partisipasi pemilih pemula pada Pilkada tahun 2020 dengan sosialisasi langsung melalui media baik media cetak maupun media online.

Pemilu dalam masa pandemic memiliki beberapa tantangan karena terdapat dua fokus bagi penyelenggara pemilu yaitu fokus dalam mewujudkan pemilu yang berkualitas dan juga fokus dalam menerapkan protokol kesehatan untuk menjaga kesehatan pemilih. Komisi 
Pemilihan Umum (KPU) Kota Bandar Lampung mencatat terdapat sekitar 6.000 pemilih pemula dari jumlah daftar pemilih tetap (DPT) 647.278 pada pemilihan wali kota dan wakil wali kota. Jumlah pemilih pemula tersebut tersebar di 20 kecamatan di Kota tapis Berseri. (Lugina, 2020).

Komisioner KPU Kota Bandar Lampung Divisi Pusat Data dan Informasi mengatakan, dalam Pilkada tahun 2020 ini terjadi peningkatan data sebanyak 2.736 DPS dibandingkan data 2019 lalu. Ika Kartika menginformasikaan kepada media bahwa "Kenaikan data ini, didominasi oleh para pemilih pemula yang ditemukan KPU dalam coklit beberapa waktu lalu (Lampungpro.co, 2020).

Tabel 4. Jumlah Partisipasi Pemilih Pemula di Kota Bandar Lampung

\begin{tabular}{clll}
\hline No. & Pemilu & Partisipasi Keseluruhan & Partisipasi Pemilih Pemula \\
\hline 1. & Pilwakot 2015 & 419.994 & 83.998 \\
2. & Pilgub 2018 & 455.975 & 91.195 \\
3. & Pilpres 2019 & 565.463 & 113.092 \\
\hline
\end{tabular}

Sumber :KPU Bandar Lampung 2020

Jumlah Partisipasi Pemilih Pemula di Kota Bandar Lampung dalam Pemilu menyatakan bahwa partisipasi pemilih pemula rata-rata $20 \%$ dalam tiga kali pemilu. Jumlah partisipasi dari hasil dari ketiga pemilu tersebut dan pilkada yang akan dilaksanakan pada 9 Desember 2020 dapat dicermati untuk menakar partisipasi pemilih pemula didalam menggunakan hak pilihnya. Adanya pandemic Covid-19 apakah akan berpengaruh dalam partisipasi pemilih pemula di pilwakot Bandar Lampung tahun 2020 inilah yang menarik untuk diteliti dalam penelitian ini.

Partisipasi politik yang menarik untuk dijadikan kajian adalah partisipasi politik para pemilih pemula, karena pemilih pemula adalah kalangan yang barumemasuki dunia politik sehingga informasi tentang politik masih minim(Jayawinangun \&Nugroho, 2019). Adanya Covid-19 membuat beberapa tahapan pilkada akan terganggu terutama kampanye yang merupakan sarana bagi pemilih pemula untuk mengetahuiinformasi tentang politik serta mengenai profil kandidat yang akan berkompetisi dalam pilkada. Mengingat pentingnya partisipasi politik pemilih pemula dalam pilkada maka perlu dilakukan kajian tentang menakar partisipasi pemilih pemula dalam pilkada dimasa pandemic Covid-19 studi di Kota Bandar Lampung.

Kajian ini bertujuan untuk menakar partisipasi pemilih pemula di Bandar Lampung dalam Pilkada serentak tahun 2020 yang diselenggarakan dimasa pandemic Covid-19. Kajian ini berbeda dengan penelitian yang sejenis karena metodenya dilakukan dengan survei online melalui kuesioner yang disebar kepemilih pemula di Bandar Lampung. Dalam Kuesioner tersebut selain pertanyaan terbuka terdapat juga pertanyaan tertutup yang disediakan oleh Penulis agar dapat mengetahui lebih dalam pendapat pemilih pemula mengenai pelaksanaan pilkada di masa pandemic Covid-19.

\section{METODE PENELITIAN}

Penelitian ini menggunakan pendekatan kualitatif. Locus penelitian berada diKota Bandar Lampung yang terdiri dari dua puluh kecamatan. Selain itu, pengumpulan data sekunder dengan dengan mengutip melalui buku, jurnal, dokumen, berita online, dan bahan lainnya. Data dianalisis menggunakan teknik statistik deskriptif, penulis akan memberikan penilaian dari setiap respon dengan menggunakan tabulasi data tunggal. Dalam penelitian ini, peneliti melakukan survey kualitatif dengan mengajukan beberapa pertanyaan kepada responden.

Penyebaran kuesioner menggunakan google form. Pertanyaan-pertanyaan yang dilakukan selain pertanyaan terikat yang peneliti ajukan, terdapat pula pertanyaan terbuka terkait pandangan dari para responden atau partisipan mengenai pemilih pemula terhadap Pilkada ditengah pandemic covid 19. Pada penelitian ini terdiri atas 112 responden yang berusia 17-21 tahun dari berbagai Kecamatan di Kota Bandar Lampung. 
Khairunnisa Maulida, Hertanto \& Robi Cahyadi Kurniawan, Menakar Partisipasi Pemilih Pemula

Tabel 5. Informasi Responden

\begin{tabular}{lcc}
\hline \multicolumn{1}{c}{ Umur } & Value & Percentage (\%) \\
\hline \multicolumn{1}{c}{17} & 18 & $16,1 \%$ \\
\multicolumn{1}{c}{18} & 12 & $10,7 \%$ \\
\multicolumn{1}{c}{21} & 24 & $21,4 \%$ \\
\hline Asal Kecamatan & 17 & $15,2 \%$ \\
\hline Teluk Betung Barat & 41 & $36,6 \%$ \\
Teluk Betung Timur & & \\
Teluk Betung Selatan & 0 & $0 \%$ \\
Bumi Waras & 2 & $1,8 \%$ \\
Panjang & 2 & $1,8 \%$ \\
Tanjung Karang Timur & 1 & $0,9 \%$ \\
Kedamaian & 1 & $0,9 \%$ \\
Teluk Betung Utara & 1 & $0,9 \%$ \\
Tanjung Karang Pusat & 2 & $1,8 \%$ \\
Enggal & 4 & $3,6 \%$ \\
Tanjung Karang Barat & 5 & $4,5 \%$ \\
Kemiling & 1 & $0,9 \%$ \\
Langkapura & 8 & $7,1 \%$ \\
Kedaton & 11 & $9,8 \%$ \\
Tanjung Senang & 10 & $8,9 \%$ \\
Rajabasa & 6 & $5,4 \%$ \\
Labuhan Ratu & 16 & $14,3 \%$ \\
Sukarame & 11 & $9,8 \%$ \\
Sukabumi & 5 & $4,5 \%$ \\
Way Halim & 11 & $9,8 \%$ \\
\hline
\end{tabular}

Sumber : Diolah Peneliti, 2020

\section{HASIL DAN PEMBAHASAN}

Dalam menakar partisipasi pemilih pemula dalam pemilihan kepala daerah di masa pandemic Covid-19 di Kota Bandar Lampung peneliti memberikan 15 pertanyaan terbuka dan 5 pertanyaan tertutup. Peneliti meringkas beberapa pertanyaan untuk menganalisis partisipasi pemilih pemula di Kota Bandar Lampung tahun 2020. Pemilih Pemula mempunyai posisi strategis dalam Pilwakot Bandar Lampung tahun 2020. Berdasarkan data KPU Kota Bandar Lampung pada Pemilihan Umum (Pemilu). Tahun 2019 jumlah partisipasi pemilih secara keseluruhan adalah 565.463 dengan partisipasi pemilih pemula sebanyak 113.092. KPU Kota Bandar Lampung mencatat terdapat sekitar 6000 pemilih pemula dari jumlah daftar pemilih tetap (DPT) 647.278 pada pemilihan wali kota dan wakil wali kota. Jumlah pemilih tersebut tersebar di 20 Kecamatan di Kota Bandar Lampung (Andala, 2020). Hasil penelitian Shaleh \& Raihana (2021) menunjukkan partisipasi pemilih pemula memiliki arti penting karena pada pilkada tahun 2020 basis pemilih pemula meningkat. Dalam bagian ini penulis menjabarkan hasil dari survey kualitatif dan pembahasan yang penulis analisis menggunakan data yang penulis peroleh

\section{Pengetahuan Pemilih Pemula}


Apakah anda mengetahui bahwa akan ada Pilwakot pada bulan Desember 2020? 112 tanggapar
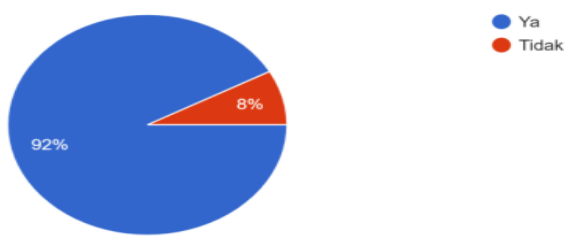

Gambar 1. Pengetahuan Pemilih Pemula terhadap Pilwakot di Kota Bandar Lampung Sumber: Diolah Peneliti (2020)

Gambar 1. Pengetahuan Pemilih Pemula terhadap Pilwakot di Kota Bandar Lampungmenunjukkan bahwa sebanyak 92\% responden mengetahui bahwa pada Bulan Desember tahun 2020 di Bandar Lampung akan diselenggarakan Pilwakot. Sementara 8\% responden tidak mengetahui bahwa akan ada Pilwakot pada Bulan Desember 2020 di Bandar Lampung. Persentase pada gambar diatas dapat disimpulkan bahwa sebagian besar dari pemilih pemula sudah mengetahui akan diselenggarakan Pilwakot pada Bulan Desember tahun 2020. Hasil penelitian Nisa \& Sari (2021) pengetahuan pemilih pemula dalam menginterpretasikan pelaksanaan pilkada adalah rasa ingin tahu, kesadaran diri, sosialisasi, APK, keluarga dan teman sebaya.

\section{Penggunaan Hak Pilih Pemilih Pemula}

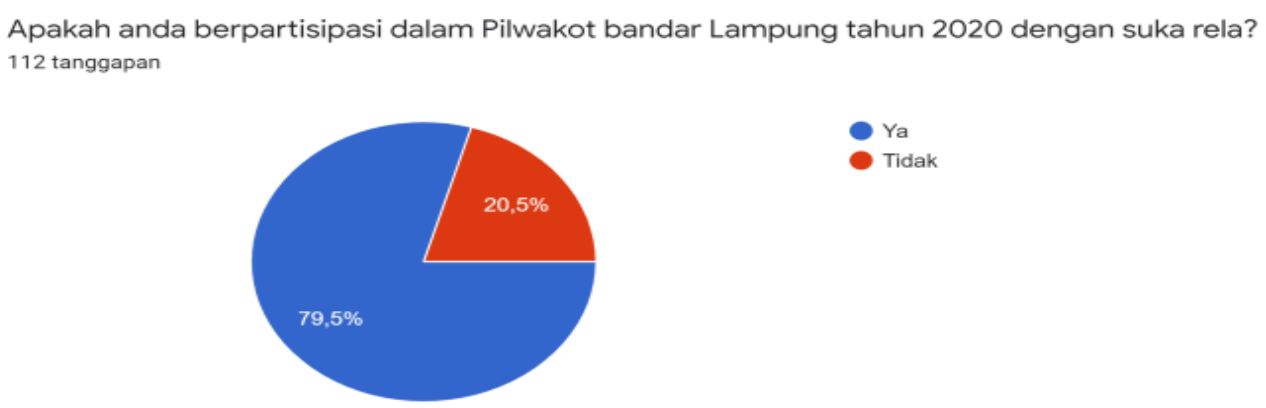

Gambar 2. Penggunaan Hak Pilih Pemilih Pemula Sumber: Diolah Peneliti (2020)

Berdasarkan Gambar 2 Penggunaan hak pemilih pemula menunjukkan bahwa 79,5\% pemilih pemula menggunakan hak pilih nya secara sukarela dan hanya 20,5\% yang menjawab tidak. Pendapat pemilih pemula tersebut selaras dengan pendapat Herbert McClosky yang mendefinisikan partisipasi politik adalah kegiatan-kegiatan sukarela dari warga masyarakat dengan mengambilbagian dalam proses pemiilhan penguasa dan secara langsung atau tidak langsung dalam proses pengambilan kebijakan umum (Budiardjo, 2008).

Banyak pro dan kontra terhadap kebijakan pemerintah dalam mengambil keputusan bahwa pilkada akan teteap dilaksanakan ditengah pandemic Covid-19. Keputusan tersebut sudah final dan pilkada akan dilaksanakan pada 9 Desember 2020. Dalam pertanyaan terbuka banyak pemilih pemula yang menjawab bahwa pentingnya menerapkan protokol kesehatan dalam pilkada di masa Pandemi agar terhindar dari Virus Covid-19. Salah satu responden memberikan jawaban yang mendukung pilkada tetap dilaksanakan dengan menerapkan protokol kesehatan, hal tersebut diungkapkan sebagai berikut:"saya setuju diadakannya pilkada ini karena memang sudah waktunya untuk melakukan pergantian kepemimpinan ditingkat daerah, karena daerah perlu pemikiran-pemikiran baru atau inovasi yang 
bisa membuat masyarakat lebih sejahtera terlebih dimasa pandemic" (INT1).

Namun terdapat juga banyak pandangan yang berbeda terkait pelaksanaan pilkada dimasa pandemic Covid-19. Hal tersebut diungkapkan sebagai berikut:"Menurut saya sebaiknya pilkada pada tahun ini ditunda terlebih dahulu, karena mengingat semakin banyaknya angka yang terdampak Covid-19, seharusnya pemerintah mencari solusi untuk bagaimana cara menurunkan cluster yang terdampak Covid-19. Demokrasi pasti akan terus berjalan, tetapi kesehatan masyarakat itu jauh lebih baik didahulukan" (INT2).

Responden lain juga memberikan jawaban serupa terkait pandangan pilkada dimasa pandemic Covid-19 dan memberikan solusi dalam sistem pemungutan suara.

"Sangat beresiko dan saya kira demi kepentingan tertentu apabila pilkada ini diselenggarakan pada masa pandemic dalam bentuk kontak sosial dengan khalayak ramai secara langsung, alangkah baiknya jika pilkada ini dilaksanakan menggunakan vote online (bagi yang mempunyai gawai) dengan sistem pengelolaan yang baik sehingga tidak menambah kasus baru didaerah masingmasing)(INT3).

Pelaksanaan pilkada dimasa pandemic Covid-19 menurut pemilih pemula beresiko karna dikhawatirkan akan menyebabkan cluster baru dalam penyebaran Covid-19. Pemilih pemula akan berpartisipasi walaupun sebenarnya pandangan mereka kurang setuju dengan pilkada diselenggarakan dimasa pandemic Covid-19. Harapan pemilih pemula adalah dengan menerapkan protokol kesehatan demi menjaga diri dari penularan virus Covid19. Alasan pemilih pemula tetap berpartisipasi dalam pilkada dimasa pandemic karena kesadaran pemilih pemula sebaga warga negara yang mempunyai hak dalam memilih pemimpin, pernyataan tersebut diungkapkan dalam Pertanyaan terbuka di google form penulis.

"Ya kita sebagai warga hak negara harus mempunyai hak suara pemimpin yang kita inginkan. Sebagai warga negara hanya mengikuti peraturan yang sudah ditetapkan oleh Presiden bahwasannya pemilu akan dilaksanakan pada tanggal 9 Desember 2020" (INT4).

Kesadaran politik warga negara menjadi faktor determinan dalam partisipasi politik masyarakat artinya sebagai hal berhubungan pengetahuan dan kesadaran akan hak dan kewajiban yang berkaitan dengan lingkungan masyarakat dan kegiatan politik yang menjadi ukuran dan kadar seseorang terlibat dalam proses partisipasi politik (Saputra, 2017). Selaras dengan pendapat Saputra tersebut berbanding lurus dengan keadaan pemilih pemula dalam Pilkada di kota Bandar Lampung tahun 2020. Pengetahuan pemilih pemula bahwa akan ada pilwakot di Bandar Lampung tahun 2020 sebesar $92 \%$ dan pemilih pemula akan berpartisipasi dalam pilwakot dengan presentase 79,5\%. Bentuk Partisipasi Pemilih Pemula dalam Pilwakot Bandar Lampung Tahun 2020

\section{Protes terhadap Kebijakan yang dibuat oleh Pemerintah}

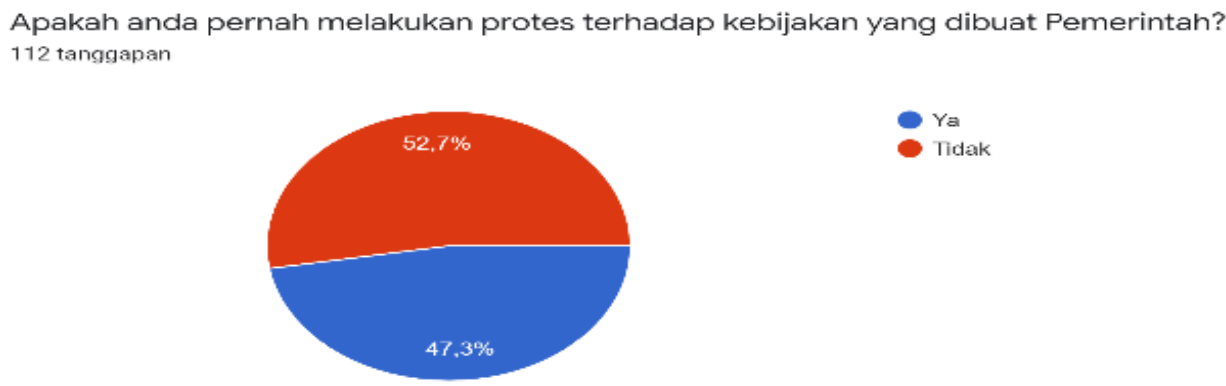

Gambar 3. Protes terhadap kebijakan yang dibuat oleh Pemerintah Sumber: Diolah Peneliti (2020)

Merujuk pada gambar 3 diketahui bahwa pemilih pemula lebih banyak menyatakan bahwa tidak pernah melakukan protes terhadap kebijakan pemerintah. Menurut 
Almond bentuk- bentuk dalam partisipasi politik adalah bentuk partisipasi konvensional dan non konvensional (Syarbaini, 2002). Berdasarkan respon dari pemilih pemula dalam pertanyaan survey kualiatatif menunjukkan bahwa pemilih pemula melakukan protes terhadap kebijakan pemerintah secara kelompok sebanyak $80,6 \%$ dan individu sebanyak 19,4\%. Protes melalui demonstrasi yang diikuti pemilih pemula terakhir yaitu berdasarkan wawancara dengan salah satu responden sebagai berikut:"Ya saya protes terhadap kebijakan pemerintah dengan mengikuti demonstrasi menolak Omnibus Law.
Covid-19 bukan penghalang saya dalam menolak kebijakan pemerintah di Kantor DPRD Provinsi Lampung karena saya tetap menerapkan protokol kesehatan" (INT5).

Protes terhadap kebijakan pemerintah melalui demonstrasi menurut Almond merupakan bentuk partisipasi nonkonvensional (Syarbaini, 2002). Pemilih pemula berpartisipasi dengan turut serta dalam protes terhadap kebijakan Pemerintah terkait OmnibusLaw. Dengan persentase 47,3\% pemilih pemula melakukan protes melalui kelompok dengan berdemonstrasi.

\section{Keikutsertaan dalam acara debat politik calon wali kota dan wakil walikota Bandar Lampung dalam Pilkada 2020}
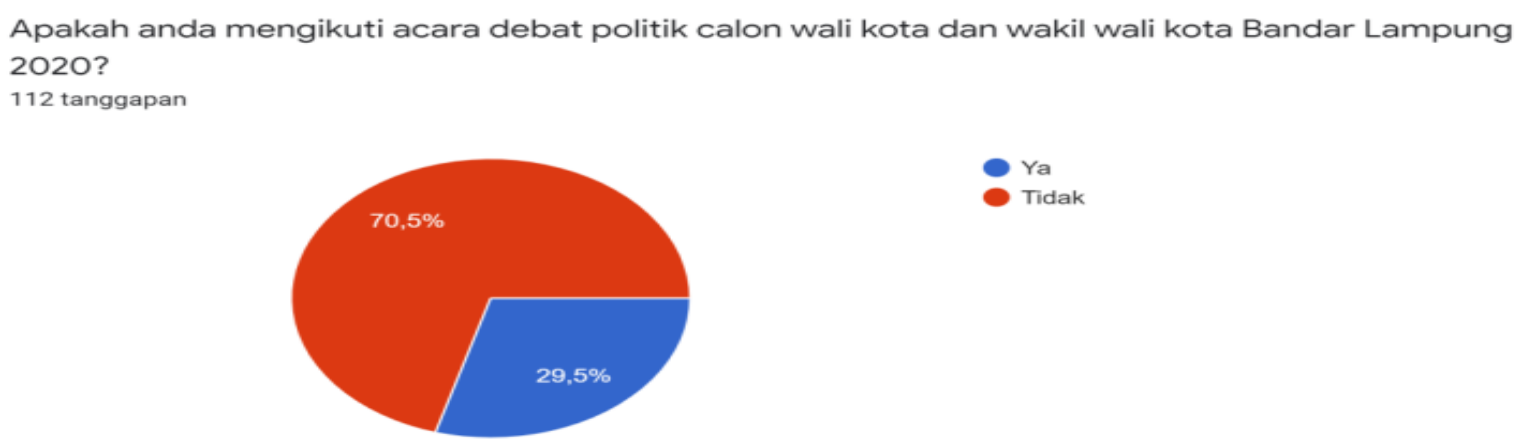

Gambar 4. Keikutsertaan pemilihpemula dalamacara debat publik Sumber: Diolah Peneliti (2020)

Merujuk pada gambar 4 bahwa lebih banyak pemilih pemula yang tidak mengikuti acara debat publik. Bentuk partisipasi pemilih pemula dalam pilkada serentak tahun 2020 tidak hanya bentuk nonkonvensional. Tetapi pemilih pemula juga masih ada yang melakukan bentuk partisipasi konvensional dengan 29,5\% mengikuti acara debat publik1 pasangan calon wali kota dan wakil wali kota Bandar Lampung.

Komisi Pemilihan Umum Kota Bandar Lampung membatasi jumlah orang yang boleh memasuki ruangan debat kandidat calon wali kota / wakil wali kota untuk menghindari kerumunan massa dalam upaya mencegah penyebaran Covid-19. Fery sebagai Divisi Teknis Penyelenggaraan menginformasikan kepada media bahwa: "jadi untuk kawankawan media dan masyarakat dapat menyaksikannya melalui live streaming melalui instagram, facebook maupun Youtube KPU Kota Bandar Lampung (Rilis.id, 2020).

Terdapat $44,6 \%$ pemilih pemula yang mengakses melalui sosial media dan sebanyak $55,4 \%$ tidak mengakses acara debat politik calon wali kota dan wakil wali kota Bandar Lampung tahun 2020. Disisi lain, David Roft dan Frank dalam (Rahman, 2007) bentuk partisipasi negara berdasarkan intensitasnya yang paling rendah adalah pengamat dan tertinggi adalah partisipan. Menurut Roth dan Wilson dalam (Rahman, 2007) kelompok paling bawah dalam piramida partisipasi politik adalah kelompok apolitis yaitu kelompok yang sama sekali tidak terlibat dan tidak melakukan kegiatan politik. Diatas Kelompok apolitis terdapat kelompok pengamat atau penonton, kelompok ini biasanya menghadiri rapat umum 
parpol, mengikuti perkembangan lewat media, dan memberikan suara dalam pemilihan umum. Selanjutnya yaitu Kelompok Partisipan, pada kelompok ini aktivitas yang sering dilakukan adalah menjadi petugas kampanye, anggota aktif partai. Kelompok paling atas adalah Aktivis yang merupakan pejabat partai sepenuh waktu, memimpin partai dan pemimpin kepentingan.

Berdasarkan intensitasnya pemilih pemula di Kota Bandar Lampung termasuk dalam kategori Pengamat atau Penonton karena berdasarkan hasil survey kualitatif yang dilakukan penulis pemilih pemula mengetahui akan adanya pilwakot dengan mengikuti perkembangan media dan mereka secara sukarela akan berpartisipasi dalam piwakot Bandar Lampung tahun 2020. Ridha \& Riwanda (2020) menyatakan bahwa literasi media dan politik memiliki pengaruh terhadap partisipasi pemilih pemula secara parsial maupun simultan. Karakter Partisipasi Pemilih Pemula dalam Pilwakot Bandar Lampung Tahun 2020

\section{Faktor Money Politic dalam Memilih Pasangan Calon}
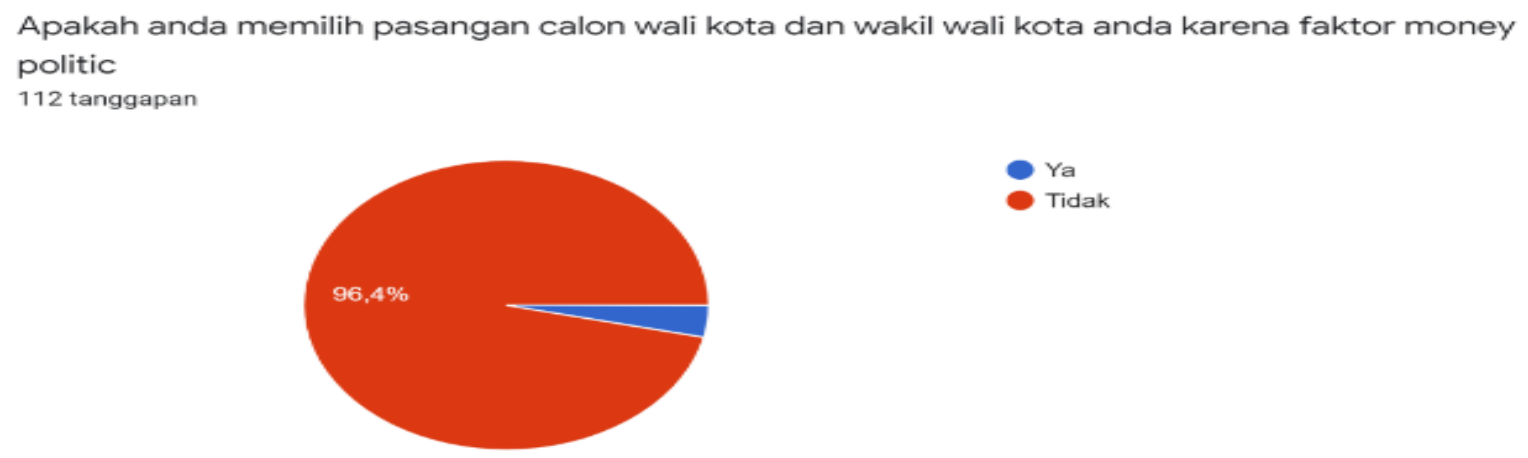

Gambar 5. Faktor Money Politic dalam Memilih Pasangan Calon Sumber: Diolah Peneliti (2020).

Gambar 5 menunjukkan bahwa pemilih pemula dalam memilih pasangan calon wali kota dan wakil wali kota tidak dipengaruhi oleh money politik dengan persentase 96,4\%. Mengenai karakter partisipasi pemilih, Huntington dan Nelson membagi kedalam dua konsep yaitu partisipasi mobilisasi dan partisipasi otonom. (Damsar,2010). Partisipasi otonom merupakan partisipasi yang dilakukan secara sukarela sedangkan yang dimaksud dengan partisipasi mobilisasi merupakan partisipasi secara tidak sadar ada tekanan dan unsur paksaan. Dengan persentase 96,4\% menunjukkan bahwa karakter pemilih pemula di Kota Bandar Lampung termasuk dalam kategori otonom. Pemilih pemula tidak terpengaruh dengan adanya politik uang (money politic). Selain itu, di dalam penjelasan sebelumnya mengenai partsipasi pemilih pemula dalam Pilwakot Bandar Lampung tahun 2020 dilakukan dengan suka rela dengan persentase 79,5 \%. Dengan begitu, pemilih pemula di dalam menggunakan hak pilihnya tidak mendapatkan intevensi dari pihak manapun maupun paksaan dari orang lain melainkan atas kesadaran sebagai warga negara yang mempunyai hak dalam memilih pemimpin. Faktor-faktor partisipasi pemilih pemula dalam Pilwakot Bandar Lampung Tahun 2020

\section{Pengaruh Orang Tua dalam Menggunakan Hak Pilih}



Apakah orang tua anda mempengaruhi anda untuk menggunakan hak pilih dalam Pilwakot Bandar
Lampung tahun $202 \mathrm{O}$ ?
112 tanggapan
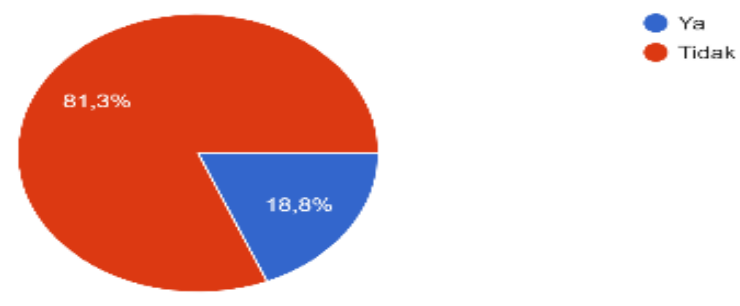

Gambar 6. Pengaruh Orang Tua dalam Menggunakan Hak Pilih Sumber: Diolah Peneliti (2020)

Merujuk pada gambar 6 bahwa orangtua tidak mempengaruhi hak pemilih pemula dalam pilwakot Bandar Lampung tahun 2020. Sebanyak 79,5\% pemilih pemula memperoleh informasi pilkwakot melalui media sosial. Hasil penelitian Prangin and Zainal (2018) menunjukkan bahwa media sosial digunakan secara masif oleh para pemilih pemula karena melalui media sosial mereka dapat berinteraksi dan berkomunikasi tanpa memerlukan persiapan fisik maupun keharusan untuk memperlihatkan atribut kepribadian secara terbuka. Informasi yang diperoleh oleh Pemilih pemula melalui media sosial merupakan salah satu faktor pemilih pemula dalam berpartisipasi dalam pilwakot Bandar Lampung tahun 2020. Pemilih pemula memiliki kecenderungan akan memilih paslon yang berkampanye di media sosial karena mudah dijangkau oleh mereka dan dianggap menarik (Nurcholis \& Putra, 2020). Responden mengungkapkan mengenai kendala dalam memperoleh informasi yang berada dalam pertanyaan terbuka di googel form. Berikut ungkap salah satu responden:"sebagai pemilih pemula dalam pilkada tersebut pastinya ada kendala yang kita alami, seperti siapa saja paslon yang terdaftar atau yang bakal menjadi calon kepala daerah, apa saja visi-misi mereka dan bagaimana program-program mereka yang sudah dijalani ataupun program-program yang akan mereka lakukan untuk memajukan daerah tersebut" (INT6)
Responden lain memberikan pernyataan yang berbeda mengeani kendala dalam memperoleh informasi mengenai pilkada. Hal tersebut diungkapkan sebagai berikut:"tidak ada kendala karena semua bisa diakses dengan sosial media" (INT7)

Berdasarkan survey kualitatif yang dilakukan oleh penulis, sebanyak $42 \%$ pemilih pemula mengetahui nama-nama pasangan calon wali kota dan wakil wali kota dari Alat Peraga Kampanye (APK).APK sebagai media pemilih pemula dalam memperolehinformasi mengenai nama-nama pasangan calon yang akan berkompetisi dalam pilkada serentak tahun 2020 di Kota Bandar Lampung. Kekurangan informasi mengenai visi- misi dan program paslon dikarenakan biasanya diperoleh melalui kampanye akbar yang diselenggarakan oleh pasangan calon, namun karena Covid-19 hal tersebut tidak dapat dilakukan demi terhindar dari virus Covid-19.

Berdasarkan penelitian Nur Wardhani (2018)Ada berbagai cara yang dilakukan oleh calon untuk menarik simpati dalam kegiatan kampanye, diantaranya dengan menghadirkan bintang hiburan baik penyanyi maupun selebriti dalam kampanye terbuka melakukan bakti sosial dan memberikan bantuan untuk pembangunan tempat ibadah, sehingga hal-hal tersebut dapat menarik perhatian pemilih khususnya pemilih pemula untuk memilih. 


\title{
Kesadaran Pemilih Pemula sebagai warga negara
}

\begin{abstract}
Apakah anda menggunakan hak pilih anda karena kesadaran anda sebagai warga negara? 112 tanggapan
\end{abstract}

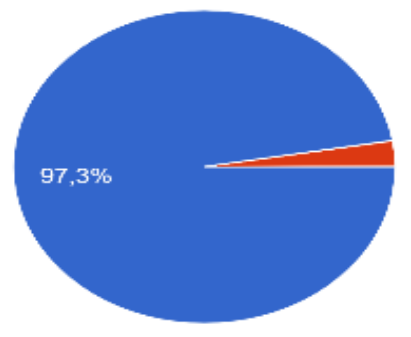

\section{Gambar 7. Kesadaran Pemilih Pemula sebagai Warga Negara}

Sumber: Diolah Peneliti (2020)

Pemilih pemula menggunakan hak pilih dalam pilwakot Bandar Lampung tahun 2020 meskipun dalam masa pandemic Covid- 19 tetapi mereka tetap berpartisipasi dengan menerapkan protokol kesehatan. Faktor-faktor partisipasi pemilih pemula di Bandarlampung dalam pilkada tahun 2020 adalah karena kesadaran mereka sendiri dalam menggunakan hak pilihnya, tidak mendapatkan paksaan ataupun dimobilisasi oleh pihak manapun termasuk orangtua.

Partisipasi pemilih pemula dipengaruhi oleh kesadaran sebagai warga negara yang harus memilih pemimpin mereka selama lima tahun kedepan. Selain itu, faktor-faktor partisipasi pemilih yang lainnya menurut hasil penelitian Azhari (2020) faktor yang mempengaruhi partisipasi politik pemilih pemula adalah rasa ingin tahu, kebijakan yang dijanjikan, visi misi paslon serta kesadaran politik pemilih pemula akan kewajiban sebagai warna negara Indonesia. Dalam penelitian ini, responden mengungkapkan faktor lain dalam partisipasi pemilih yaitu sebagai berikut:"Ya saya memilih pasangan calon itu karena visi misi mereka, program mereka yang akan dijalankan, latar belakang (track record) mereka juga penting" (INT8)

Disisi lain, didalam pertanyaan tertutup terdapat ungkapan responden mengenai saran untuk penyelenggara KPU agar terciptanya pemilu yang berintegritas walaupun di masa pandemic seperti sekarang ini. Berikut ungkapan responde dalam google form yang disediakan penulis:"untuk KPU harus lebih ekstra lagi dalam melaksanakan penyelenggara pilkada ini karena yang kita ketahui bersama di dalam setiap pemilihan umum pastinya akan ada perkumpulan-perkumpulan masyarakat yang bisa menyebabkan bertambahnya claster Covid-19. Kpu harus bisa mengatasi permasalahan ini dengan bekerja sama dengan instansi lain seperti Bawaslu, TNI dan Polri"(INT9). KPU harus memiliki strategi khusus pada pilkada di masa pandemi yaitu dengan memaksimalkan sosialisasi melalui media dan virtual dengan menyelenggarakan webinar (Fadhila \& Erowati, 2021).

Responden lain mengungkap jawaban yang serupa. Jawaban responden tersebut adalah sebagai berikut:"intinya pemilu harus berlandaskan luber jurdil dan sangat amat menetapkan protokol kesehatan seperti mewajibkan memakai masker, menyediakan hand sanitizer dan jaga jarak" (INT10).

Pemilih pemula merupakan pemilih baru yang akan menggunakan hak pilihnya dalam pemilu atau pemilih yang berusia 17-21 tahun pada saat pemilihan. Pemilih pemula mempunyai pengalaman dan tantangan yang berbeda dengan pemilih lainnya. Walaupun adanya Covid-19 membuat pemilih pemula tetap berpartisipasi untuk menggunakan hak pilihnya sebagai warga negara dengan harapan tetap menerapkan protokol kesehatan. Media sosial merupakan sarana yang digunakan pemilih pemula dalam memperoleh informasi mengenai pilkada ditengah pandemic Covid-19.

\section{SIMPULAN}

Dalam penelitian ini membahas mengenai pengetahuan pemilih pemula terkait pilkada ditengah pandemic yang akan diselenggarakan 9 Desember 2020. Pemilih 
pemula akan berpartisipasi dalam memberikan suara di pilkada serentak walaupun ditengah pandemic dengan menerapkan protokol kesehatan. Pengaruh media sosial juga menjadi faktor partisipasi pemilih pemula karena melalui media sosial pemilih pemula mengakses informasi terkait pilkada di Kota Bandar Lampung tahun 2020. Walaupun menurut pandangan pemilih pemula pelaksanaan pilkada dimasa pandemic Covid19 bukan merupakan suatu hal yang wajar karena dapat menjadi cluster baru dalam penyebaran Covid-19.

Harapan dari pemilih pemula KPU menjalankan tugasnya dalam menyelenggarakan pilkada yang demokratis dengan tetap memperhatikan protokol kesehatan. Dimasa pandemi Covid-19 pemilih pemula menggunakan media sosial untuk mengakses informasi termasuk informasi politik berkaitan dengan pilkada serentak tahun 2020.

\section{DAFTAR PUSTAKA}

Andala, S. (2020). Pemilih Pemula di Bandar LampungMencapai 6000. Lampost.Co. diunduh di https://m.lampost.co/beritapemilih-pemula-di-bandar-lampungmencapai-6000/tanggal 07 November 2020.

Arifin, A. (2011). Komunikasi Politik: FilsafatParadigma-Teori-Tujuan-Strategi dan Komunikasi Indonesia. Yogyakarta: Graha Ilmu.

Azhari, A. M., Pebriyenni, \& Yusrizal. (2020). Partisipasi Politik Pemilih Pemula dalam Pemilihan Walikota Padang tahun 2018. Tesis. Universitas Bung Hatta.

Budiardjo, M. (2008). Dasar-Dasar Ilmu Politik. Jakarta : PT Gramedia Pustaka.

Damsar. (2010). Pengantar Sosiologi Politik. Jakarta : Kencana Prenada Media Group.

Fadhila, S. Y., \& Erowati, D. (2021). Strategi Meningkatkan Partisipasi Masyarakat dalam Pilkada Serentak 2020 di Masa Pandemi Covid-19. POLITEA : Jurnal Politik Islam, 4(1), 63-92.

Hamzah, H. (2020). Pilkada vs Pandemi, dan Pengalaman Negara Lain. Tesis. Universitas Mulawarman.

Jayawinangun, R., \& Nugroho, D. R. (2019). Segmentasi Pemilih Pemula Berdasarkan Akses Berita Politik Melalui Media Sosial di Kabupaten Bogor. Jurnal Komunikasi Pembangunan, 17(02), 157-164.

Kemenkes RI. (2020). Pedoman Pencegahan dan Pengendalian Corona Virus Disease (COVID-
19) Rev 3. Direktorat Jenderal Pencegahan dan Pengendalian Penyakit.

Kim, D. (2020). Democracy in the Time of COVID-19: South Korea's Legislative Election. Www.Asiapacific.Ca.

https://www.asiapacific.ca/publication/de mocracy-time-covid-19-south-koreaslegislative-election/ tanggal 14 November 2020.

Lampungpro.co. (2020). Pilkada Bandar Lampung Tahun 2020, KPU Catat Daftar Mata Pilih Meningkat 2.763. Lampungpro.Co. https://lampungpro.co/post/29883/pilkada -bandar-lampung-tahun-2020-kpu-catatdaftar-mata-pilih-meningkat-2763/tanggal 15 November 2020

Lugina, M. C. (2020). Pemilih Pemula di Bandar Lampung Mencapai 6.000. Www.Lampost.Co. https://www.lampost.co/berita-pemilihpemula-di-bandar-lampung-mencapai-6000.html/tanggal 15 November 2020

Mashabi, S. (2020). Ini Strategi Yang dilakukan KPU Jelang Pilkada Ditengah Pandemi Covid-19. Nasionalkompas.Com. diunduh di https://nasional.kompas.com/read/2020/1 1/09/13312891/ini-strategi-yangdilakukan-kpu-jelang-pilkada-di-tengahpandemi-covid-19/tanggal 15 November 2020

Mursyid, S., \& Larissa, D. (2021). Peran KPU dalam Meningkatkan Partisipasi Pemilih Pemula pada Pilkada Kabupayen Bulukumba Perspektif Siyasah Syari'ah. Siyasatuna, 3(2), 442-453.

Nisa, N. R., \& Sari, M. M. K. (2021). Pengetahuan Pemilih Pemula di Desa Margomulyo pada Pelaksanaan Pilkada Kabupaten Trenggalek 2020 dimasa Pandemi Covidd-19. Kajian Moral Dan Kewarganegaraan, 9(3), 626-640.

Wardhani, P. S. N. (2018). Partisipasi Politik Pemilih Pemula dalam Pemilihan Umum. Jupiis: Jurnal Pendidikan Ilmu-Ilmu Sosial, 10(1), 57-62.

Nurcholis, A., \& Putra, T. R. (2020). Pengaruh Media Sosial terhadap Partisipasi Pemilih Pemula pada Pemilihan Presiden 2019: Studi pada Mahasiswa FISIPOL UGM. Jurnal PolGov, 2 (1), 193-222.

Nurgiansah, T.H. (2021). Partisipasi Politik Masyarakat Sleman di Masa Pandemi Covid19 dalam Konteks Pendidikan Kewarganegaraan. Jurnal Civic Hukum, 6(1), 1-9.

Prangin, L. L. K., \& Zainal, M. (2018). Partisipasi Politik Pemilih Pemula dalam Bingkai Jejaring Sosial di Media Sosial. ASPIKOM, Vol. 3(No. 4). 737-752

Rahman, A. (2007). Sistem Politik Indonesia. Yogyakarta : Graha Ilmu. 
Khairunnisa Maulida, Hertanto, Robi Cahyadi Kurniawan, Menakar Partisipasi Pemilih

Ridha, M., \& Riwanda, A. (2020). Literasi Media, Literasi Politik dan Partisipasi Kewarganegaraan Pemilih Pemula di Era Digital. Jurnal Ilmiah Pendidikan Pancasila Dan Kewarganegaraan, 5(1), 110-121.

Saputra, R. (2017). Partisipasi Politik Pemilih Pemula Pada Pemilihan Presiden di Kecamatan Mandau Kabupaten Bengkalis Tahun 2014. Jom Fisip, 4(01) 1-12

Shaleh, A. I., \& Raihana. (2021). Efektivitas Partisipasi Pemilih Pemula pada Pemilihan Kepala Daerah Tahun 2020 pada Era Covid19 di Indonesia. Jurnal Al Azhar Indonesia Seri Ilmu Sosial, 2(1), 1-6.

Spinelli, A. (2020). Menyelenggarakan Pemilu di Tengah Pandemi Covid-19: Ujian Krusial Repbulik Korea. International IDEA 2.

Syarbaini, S, dkk. (2002). Sosiologi dan Politik. Ghalia Indonesia.

Widodo, Y., Gama, B., \& Kusumastuti, H. S. (2018, December). Tingkat Partisipasi Politik Pemilih Pemula Faktor Penentu Keberhasilan
Pemilu. In Seminar Nasional Ilmu Komunikasi Politik 2018 (Vol. 1).

Daeli, S., Batubara, B., \& Jamil, B. (2021). Peranan Badan Pengawas Pemilu dalam Penyelesaian Sengketa Pada Pemilihan Legislatif Tahun 2019 Di Kota Medan. Strukturasi: Jurnal Ilmiah Magister Administrasi Publik, 3(2), 165-175.

doi:https://doi.org/10.31289/strukturasi.v3 i2.746

Ginanjar, A., Herdiansah, A., \& Sumadinata, R. (2021). Ulama dalam Politik Pemilu pada Pemilihan Gubernur DKI Jakarta 2017. Journal of Education, Humaniora and Social Sciences (JEHSS), 3(3), 853-861. doi:https://doi.org/10.34007/jehss.v3i3.414

Siahaan, M., Isnaini, I., \& Nasution, M. (2021). Peran Badan Pengawas Pemilu dalam Penanganan Tindak Pidana Pemilu di Kabupaten Simalungun. Journal of Education, Humaniora and Social Sciences (JEHSS), 4(2), 1209-1221. doi:https://doi.org/10.34007/jehss.v4i2.881 